\title{
Diagnostic Value of High Resolution Neck ultrasongraghy, Fine Needle Aspiration Cytology and BRAFV600E Mutation in Diagnosis of Malignant Thyroid Nodules
}

\author{
Marwa Sayed $^{1 *}$, Marwa EL Sharkawy ${ }^{2}$, Hussein Okasha ${ }^{1}$, Husam Hussien ${ }^{3}$, Randa F Salam ${ }^{1}$, Waled Al Nabaoy ${ }^{4}$, \\ Marianne Samir Makboul², Usama AA Sharaf El Din ${ }^{1}$ and Mona Mansour Salem
}

${ }^{1}$ Internal medicine Department, Cairo University, Egypt

${ }^{2}$ Clinical and Chemical Pathology Department, Cairo University, Egypt

${ }^{3}$ Pathology Department, Cairo University, Egypt

${ }^{4}$ Internal medicine department, Beny Sweef University, Egypt

Submission: April 24, 2017; Published: May 30, 2017

*Corresponding author: Marwa Sayed, MD, Department of internal medicine, Faculty of medicine, Cairo University, Egypt, Tel: 00201117313353; Email: meramar_s@hotmail.com

\begin{abstract}
Background: Thyroid malignancy is rapidly raising, nearly $9-15 \%$ of the thyroid nodules are malignant nodules. Finding an optimal mean to diagnose malignant thyroid nodule preoperative is a challenge. Combination of molecular analysis, imaging and cytopathology may be helpful. This study aimed to evaluate the value of adding BRAFV600E analysis to nodules with suspicious ultra-sonographic criteria.

Patients and methodology: 50 patients from Kasr alainy endocrine outpatient clinic with solitary or multiple thyroid nodules are included, All patients subjected to full history and examination, thyroid profile, high resolution neck High resolution neck ultrasound (U/S), Fine needle Aspiration Cytology (FNAC), U/S guided FNAC and BRAFV600E analysis on FNAC using DNA sequencing then high resolution melt curve analysis (HRMA) for confirmation.

Results: The incidence of BRAFV600E mutation among papillary thyroid cancer (PTC) patients was 55.6\%. it's sensitivity $42.9 \%$, specificity was $100 \%$ in diagnosing PTC. Sensitivity of high resolution neck ultrasonograghy in detecting malignancy was $88.2 \%$, specificity $72.7 \%$. Addition of ultrasonography to BRAFV600E analysis increased ultrasound sensitivity in detecting PTC preoperative to $92 \%$. There was a positive correlation between most suspicious ultrasonography findings and presence of BRAFV600E mutation (increased AP/T diameter, Increase intra-nodular blood flow, cervical lymphadenopathy, absent or incomplete halo (all $p$ value $<0.001$ ), irregular border $p$ value 0.004 , micro calcifications p value 0.007
\end{abstract}

Conclusion: Adding BRAF-V600E analysis to work up of suspicious thyroid nodule would increase the sensitivity of preoperative diagnosis of PTC especially in cases of indefinite pathological findings. HRMA is simple, low cost tool for BRAF-V600E analysis in comparison to DNA sequencing method.

Keywords: Thyroid nodule; Thyroid cancer; High resolution neck ultrasound (U/S); Fine needle aspiration cytology (FNAC); BRAFV600E mutation

Abbreviation: (U/S): High Resolution Neck Ultrasound; FNAC: Fine Needle Aspiration Cytology, PTC: Papillary Thyroid Cancer; HRMA: High Resolution Melt Curve Analysis

\section{Introduction}

Thyroid nodules is a common problem their prevalence reaching $35 \%$ by ultrasound examination in some studies [1] and $8-65 \%$ in autopsy data [2] There is an increasing rate of thyroid cancer incidence worldwide, 9 15\% of all thyroid nodules are malignant $[3,4]$. Accordingly the initial evaluation of thyroid nodule should focus on exclusion of malignancy [3]. 
High resolution $\mathrm{U} / \mathrm{S}$ is the most sensitive diagnostic imaging technique for the detection of the thyroid nodules [4], it can characterize suspicious nodules by some sonographic [5], but it depends on the skills and accuracy of the operator [6].

FNAC is the most important step in the work up of the thyroid nodule; Diagnostic accuracy has improved using US needle localization due to a decreased number of inadequate specimens and false negative results [7]. The pathology report from FNAB according to Bethesda may be read as non-diagnostic, benign, indeterminate lesion (atypia or follicular lesion of undetermined significance), Follicular neoplasm or suspicious for follicular neoplasm, Suspicious for malignancy and malignant $[8,9]$. Benign lesions on FNAB have an approximate 3\% risk of malignancy (vary with patient population), and may be followed clinically with ultrasound or with a repeat FNAB [9], which, if also benign, decreases the risk of a false negative to $1.3 \%$ [10], the only malignant pathology reliably diagnosed through FNAB is papillary thyroid carcinoma, as features such as 'Orphan Annie' nuclei, nuclear grooves, intra-nuclear inclusions, and psammoma bodies can be sufficient for a diagnosis [11]. Benign and malignant follicular neoplasms and oncocytic (Hurthle cell) adenomas and carcinomas cannot be distinguished on the basis of cytology alone, as tissue architecture is required to make the diagnosis of malignancy through observation of capsular or angio-lymphatic invasion [12].

Indeterminate cytology findings vary from $15 \%$ to $25 \%$ [13]. Indeterminate FNAC results and cyto-diagnostic errors are unavoidable due to overlapping cytological features particularly among hyperplastic adenomatous nodules, follicular neoplasms and follicular variants of papillary carcinoma [14]. The correlation of U/S features with FNAB results helps to overcome Table 1: Descriptive Data. the limitations of FNAB alone [15] even when cytological results were the same, the malignancy rate was higher when nodules had suspicious U/S findings [16], So, U/S features and FNAB results are complementary to each other [17].

From that comes the importance of a new diagnostic tool to solve the problem, to overcome the limitations of FNA and to avoid unnecessary surgery. Several molecular factors have been added to improve the diagnostic accuracy of U/S-guided FNAB $[2,18]$ one of the promising genetic factors is the analysis of the V600E mutation $[19,20]$.

\section{Aim of the Work}

To detect an accurate and useful tool for early preoperative determination of thyroid malignancy in the patients with thyroid nodule and assess its value in addition to the previous modalities (ultrasonography, and FNAC) that may increase the diagnostic accuracy and prevent unnecessary surgery

\section{Patients and Methods}

This single group comparative descriptive study included 50 patients from Kasr Alainy endocrine outpatient clinic, Cairo University.The thyroid examined contained either solitary or multiple nodules. Four patients with four nodules were hypothyroid $(8 \%)$, and two nodules were in hyperthyroid patients (4\%), and the remaining part 44 nodules were in euthyroid patients (88\%).18 examined nodules were solitary nodule and 32 were a nodule in MNG. Nodules' size ranges from $0.6-28 \mathrm{~mm}^{3}$, Mean $6.6 \mathrm{~mm}^{3} \pm 5.8 \mathrm{~mm}^{3} \mathrm{SD}$, Median $6.0 \mathrm{~mm}^{3}$. Patients'

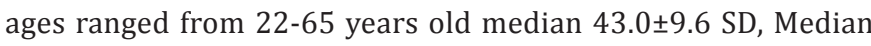
43.5. five males (10\%) and 45 females (90\%). Demographic data are included in Table 1.

\begin{tabular}{|c|c|c|}
\hline & Frequency (n=5) & 10 \\
\hline Male & 5 & 90 \\
\hline Female & 45 & 52 \\
\hline Nodule site & 26 & 44 \\
\hline Right lobe & 22 & 2 \\
\hline Left lobe & 1 & 2 \\
\hline Ismuth & 1 & 64 \\
\hline Whole gland & & 36 \\
\hline Count & 32 & \\
\hline Single & 18 & 4 \\
\hline MNG & & \\
\hline Thyroid profile & 2 & 88 \\
\hline Hyperthyroidism & 4 & \\
\hline Hypothyroidism & 44 & \\
\hline Euthyroid & & \\
\hline U/S & 24 & \\
\hline Suspicious & & \\
\hline
\end{tabular}


Journal of Endocrinology and Thyroid Research

\begin{tabular}{|c|c|c|}
\hline Not suspicious & 26 & 52 \\
\hline LNS & & 9 \\
\hline Present & 4 & 52 \\
\hline Absent & 46 & 34 \\
\hline Pathology & 28 & 10 \\
\hline Benign & 17 & 29.4 \\
\hline Malignant & 5 & 70.6 \\
\hline Indefinite & 5 & \\
\hline Malignant type (n=17) & 12 & \\
\hline Follicular neoplasm & & \\
\hline Papillary carcinoma & $6 / 47$ & \\
\hline (n=47) & $41 / 47$ & \\
\hline BRAF v600E Mutation & & \\
\hline No mutation & & \\
\hline
\end{tabular}

\section{All patients were subjected to}

i. Full clinical history including age, sex, past history of head and neck irradiation and positive family history of thyroid cancer.

ii. Thyroid examination.

iii. Thyroid profile (FT3, FT4, and TSH).

iv. High resolution neck ultrasound.

v. U/S guided FNAC.

vi. BRAFV600E analysis.

\section{Ethical considerations}

All patients were informed about these types of investigations and for confidentiality their names were omitted and replaced by numerical codes.

\section{Sonographic criteria for thyroid nodules include}

Echogenicity, Presence or absence of calcification and its types, A-P to Transverse diameter ratio, Blood flow in the nodule and its patterns whether central or peripheral or both, Solitary or dominant nodules, Presence or absence of halo, Solid, cystic or partially solid and partially cystic, Sharpness of border.

\section{Signs of increase risk of malignancy in $U / S$ include}

a. Hypo-echogenicity. Micro- or interrupted rim calcifications, Irregular Margins.

b. Absence of Halo or incomplete halo.

c. Increased Intra-nodular flow.

d. Increase antro- posterior to transverse diameter $(\mathrm{AP} / \mathrm{T})$ diameter.

e. Significant increase in size over time.

f. Invasion of anterior strap muscles g. Presence of abnormal cervical lymphadenopathy.

All cytology specimens were obtained under ultrasound guidance using a 21-gauge needle attached to a plastic syringe, part of the smear obtained were wet fixed in 95\% ethyl alcohol and stained with hematoxylin and eosin stain for routine cytological evaluation, and the other part put in test tube with saline for genetic examination.

\section{Molecular genetic testing}

Specimen collection: Samples were collected from each subject in sterile containers for the genotyping technique. Samples were either processed fresh or were stored at $2-8{ }^{\circ} \mathrm{C}$.

DNA extraction: This was performed using Thermo Scientific Gene JET Whole Blood Genomic DNA Purification Mini Kit supplied by Thermo Scientific Fermentas. The extracted DNA then subjected to the algorithm for molecular detection of BRAFV600E mutation. The aim of the current study is the detection of the most common mutation in the BRAF gene. V600E in DNA samples collected from thyroid nodules.

We used DNA sequencing method for BRAF V600E mutation detection, unfortunately all samples were BRAF V600E mutation negative, so we tried more accurate method (HRMA), then DNA sequencing for validation of the mutant BRAF results had done.

\section{The extracted DNA were conducted to the work as follows}

Extracted DNA DNA sequencing of exon 15 HRMA DNA sequencing for validation of the mutant BRAF results

\section{DNA amplification using the polymerase chain reaction}

DNA amplification using the PCR: Enzymatic amplification was performed by PCR using HotStarTaq ${ }^{\circledR}$ Master Mix Kit (250 units) supplied by QIAGEN ${ }^{\circledR}$ and BIO RAD T100TM Thermal Cycler*. 
Detection of PCR amplification products: Fluorescent stained DNA was detected by using Agarose Gel Electrophoresis and Ultra-Violet Light Trans-illumination.

Table 2: U/S Characteristics for the nodules included in the study.

\begin{tabular}{|c|c|c|}
\hline US findings & Frequency $(n=50)$ & $\%$ \\
\hline \multicolumn{3}{|l|}{ Nodules Number } \\
\hline Single & 32 & 64 \\
\hline MNG & 18 & 36 \\
\hline \multicolumn{3}{|l|}{$\mathrm{AP} / \mathrm{T}$} \\
\hline$<1$ & 31 & 62 \\
\hline$\geq 1$ & 19 & 38 \\
\hline \multicolumn{3}{|l|}{ Echogenicity } \\
\hline Hypoechoic & 32 & 64 \\
\hline Hyperecoic & 2 & 4 \\
\hline Isoechoic & 4 & 8 \\
\hline Heterogeneous & 12 & 24 \\
\hline \multicolumn{3}{|l|}{ Halo } \\
\hline Present & 36 & 72 \\
\hline Interrupted & 4 & 8 \\
\hline Absent & 10 & 20 \\
\hline \multicolumn{3}{|l|}{ Border } \\
\hline Well-defined & 36 & 72 \\
\hline Ill-defined & 14 & 28 \\
\hline \multicolumn{3}{|l|}{ Breakdown } \\
\hline Central & 16 & 32 \\
\hline Peripheral & 9 & 18 \\
\hline Central + Peripheral & 5 & 10 \\
\hline No breakdown & 20 & 40 \\
\hline \multicolumn{3}{|l|}{ Calcification } \\
\hline Present & 23 & 46 \\
\hline Absent & 27 & 54 \\
\hline \multicolumn{3}{|l|}{ Calcification type $(n=23)$} \\
\hline Micro & 20 & 87 \\
\hline Coarse & 2 & 8.7 \\
\hline Patchy & 1 & 4.3 \\
\hline \multicolumn{3}{|l|}{ Blood flow } \\
\hline Central & 12 & 24 \\
\hline Peripheral & 27 & 54 \\
\hline Central + Peripheral & 9 & 18 \\
\hline No & 2 & 4 \\
\hline \multicolumn{3}{|l|}{ LNS } \\
\hline Present & 4 & 8 \\
\hline Absent & 46 & 92 \\
\hline
\end{tabular}

Purification of PCR product: This was performed using QIAquick® PCR Purification Kit supplied by QIAGEN@ (Table 2). 
Sequencing coding sequence and intronic boundaries of Exon 2 and Exon 3 in INS gene Cycle Sequencing: Using the Applied Biosystems* (ABI) PRISM® BigDye ${ }^{\circledR}$ Cycle Sequencing Ready Reaction Kit.

Second purification: Removal of excess Dye DeoxyTM terminators from sequencing reactions by using Centri-Sep columns (Princeton separations) Terminator v3.1 Completed DNA long Read capillary electrophoresis on the ABI 3500.

\section{Analysis of data}

Sequences were compared to the published Reference sequence of Homo sapiens (BRAF), NCBI (National Centre of Biotechnology Information): (NG_007873.3, NM_004333.4, and NP_004324.2) Analysis was done by BLAST (Basic Local Alignment Search Tool) (www.ncbi.nlm.nih.gov) and the CLCBIO sequence viewer 6 program (www.clcbio.com ).

High resolution melt curve analysis: The HRMA reaction was done according to the protocol of the kit MeltDoctor TM HRM Master Mix Applied Biosystems, USA.

DNA sequencing for validation of the BRAF mutant results: The samples with mutant results were processed after HRM analysis by pipetting the reaction from the reaction tubes

Table 3: Association between different variables with malignancy and BRAF v600E mutation.

\begin{tabular}{|c|c|c|c|c|c|c|c|c|c|c|}
\hline \multicolumn{5}{|c|}{ Pathology } & \multicolumn{5}{|c|}{ Sequencing or HRMA results } & \multirow[t]{3}{*}{$\begin{array}{c}P \\
\text { value }\end{array}$} \\
\hline & \multicolumn{2}{|c|}{ Malignant $(n=17)$} & \multicolumn{2}{|c|}{$\begin{array}{l}\text { Non-malignant } \\
\qquad(n=33)\end{array}$} & \multirow[t]{2}{*}{$P$ value } & \multicolumn{2}{|c|}{ Mutation $(n=6)$} & \multicolumn{2}{|c|}{$\begin{array}{l}\text { No mutation } \\
\quad(n=41)\end{array}$} & \\
\hline & $\mathbf{N}$ & $\%$ & $\mathbf{N}$ & $\%$ & & $\mathbf{N}$ & $\%$ & $\mathbf{N}$ & $\%$ & \\
\hline \multicolumn{11}{|c|}{ Sex } \\
\hline Male & 1 & 5.9 & 4 & 12.1 & 0.7 & & & & & \\
\hline NS & 1 & 16.7 & 4 & 9.8 & 0.5 & & & & & \\
\hline Female & 16 & 94.1 & 29 & 87.9 & & 5 & 83.3 & 37 & 90.2 & NS \\
\hline \multicolumn{11}{|c|}{ Nodule site } \\
\hline Right lobe & 9 & 52.9 & 17 & 51.5 & 0.5 & & & & & \\
\hline NS & 2 & 33.3 & 22 & 53.7 & 0.7 & & & & & \\
\hline Left lobe & 7 & 41.2 & 15 & 45.5 & & 4 & 66.7 & 17 & 41.5 & NS \\
\hline Ismuth & 0 & 0.0 & 1 & 3 & & 0 & 0.0 & 1 & 2.4 & \\
\hline Whole gland & 1 & 5.9 & 0 & 0.0 & & 0 & 0.0 & 1 & 2.4 & \\
\hline \multicolumn{11}{|c|}{ Count } \\
\hline Single & 12 & 70.6 & 20 & 60.6 & 0.5 & & & & & \\
\hline NS & 4 & 66.7 & 26 & 63.4 & 1 & & & & & \\
\hline MNG & 5 & 29.4 & 13 & 39.4 & & 2 & 33.3 & 15 & 36.6 & NS \\
\hline \multicolumn{11}{|c|}{ Thyroid profile } \\
\hline Hyperthyroidism & 0 & 0.0 & 2 & 6.1 & 0.5 & & & & & \\
\hline NS & 0 & 0.0 & 2 & 4.9 & 0.6 & & & & & \\
\hline Hypothyroidism & 1 & 5.9 & 3 & 9.1 & & 0 & 0.0 & 4 & 9.8 & NS \\
\hline Euthyroid & 16 & 94.1 & 28 & 84.8 & & 6 & 100 & 35 & 85.4 & \\
\hline \multicolumn{11}{|c|}{$\mathrm{U} / \mathrm{S}$} \\
\hline
\end{tabular}

followed by purification of the products.

Statistical analysis: Pre-coded data was entered on the computer using "Microsoft Office Excel Software" program (2010) for windows. Data was then transferred to the Statistical Package of Social Science Software program, version 21 (SPSS) to be statistically analyzed.

Data was summarized using range, mean, standard deviation and median for quantitative variables and frequency and percentage for qualitative ones. Comparison between groups was performed using independent sample t-test or Mann Whitney test for quantitative variables and Chi square or Fisher's exact test for qualitative ones. $P$ values less than 0.05 were considered statistically significant, and less than 0.01 were considered highly significant.

\section{Results}

There is no statistically significant association between different sex, nodular site, count and thyroid functions with malignancy or BRAFv600E gene mutation (Table 3). Pathology results showed 28 benign nodules, 17 malignant nodule (12 papillary -5 follicular neoplasm) and 5 cases with indefinite nodules. The incidence of BRAF V600E gene mutation in our patients with PTC was 55.6\% 


\section{Journal of Endocrinology and Thyroid Research}

\begin{tabular}{|c|c|c|c|c|c|c|c|c|c|c|}
\hline Suspicious & 15 & 88.2 & 9 & 27.3 & $<0.001$ & & & & & \\
\hline $\mathrm{S}$ & 5 & 83.3 & 16 & 39 & 0.08 & & & & & \\
\hline Not suspicious & 2 & 11.8 & 24 & 72.7 & & 1 & 16. 7 & 25 & 61 & NS \\
\hline \multicolumn{11}{|c|}{ LNS } \\
\hline Present & $\begin{array}{c}4 \\
23.5 \\
\end{array}$ & 0 & 0.0 & 0.001 & & & & & & \\
\hline S & 4 & 66.7 & 0 & 0.0 & $<0.001$ & & & & & \\
\hline Absent & $\begin{array}{c}13 \\
76.5\end{array}$ & 33 & 100 & & 2 & 33.3 & 41 & 100 & S & \\
\hline
\end{tabular}

50 nodules were included but unfortunately because of repetition of genetic analysis for BRAF V600E gene mutations by DNA sequencing then again by HRMA methods that leads to that 3 samples were not enough to complete genetic analysis so BRAF V600E analysis completed only in 47 samples.

We found a positive correlation with significant $p$ value between some suspicious sonographic criteria and malignancy and some suspicious sonographic criteria and BRAF V600E mutation as increased $(\mathrm{AP} / \mathrm{T})$ diameter, absent or interrupted halo, micro-calcifications, increase intra-nodular blood flow, presence of suspicious LNs and irregular border with increased both sensitivity and specificity (Table $4 \& 5$ ).

Table 4: BRAF v600E gene mutation among different cytological groups and its $p$ value.

\begin{tabular}{|c|c|c|c|c|c|}
\hline & \multicolumn{4}{|c|}{ Sequencing or HRM results } & \multirow[t]{3}{*}{$P$ value } \\
\hline & \multicolumn{2}{|c|}{ Mutation $(n=6)$} & \multicolumn{2}{|c|}{ No mutation $(n=41)$} & \\
\hline & $\mathbf{N}$ & $\%$ & $\mathbf{N}$ & $\%$ & \\
\hline Pathology & & & & & $<0.001 \mathrm{~S}$ \\
\hline Benign & 0 & 0.0 & 28 & 68.3 & \\
\hline Malignant & 6 & 100 & 8 & 19.5 & \\
\hline Indefinite & 0 & 0 & 5 & 12.2 & \\
\hline
\end{tabular}

Table 5: Association between malignancy and BRAF v600E mutation with each parameter of US.

\begin{tabular}{|c|c|c|c|c|c|c|c|c|c|c|}
\hline \multirow{3}{*}{ U/S Criteria } & \multicolumn{4}{|c|}{ Pathology } & \multirow{3}{*}{$P$ value } & \multirow{2}{*}{\multicolumn{2}{|c|}{$\begin{array}{c}\text { BRAF v600E analysis } \\
\text { Mutation }(n=6)\end{array}$}} & & & \multirow{3}{*}{$P$ value } \\
\hline & \multicolumn{2}{|c|}{ Malignancy $(n=17)$} & \multicolumn{2}{|c|}{ Non-malignant $(n=33)$} & & & & \multicolumn{2}{|c|}{ No mutation $(n=41)$} & \\
\hline & $\mathbf{N}$ & $\%$ & $\mathbf{N}$ & $\%$ & & $\mathbf{N}$ & $\%$ & $\mathbf{N}$ & $\%$ & \\
\hline \multicolumn{11}{|l|}{$\mathbf{A P} / \mathbf{T}$} \\
\hline$<1$ & 3 & 17.6 & 28 & 84.8 & \multirow{2}{*}{$<0.001 \mathrm{~S}$} & 0 & 0.0 & 30 & 73.1 & \multirow{2}{*}{$<0.001 \mathrm{~S}$} \\
\hline$\geq 1$ & 14 & 82.4 & 5 & 15.2 & & 6 & 100 & 11 & 26.9 & \\
\hline \multicolumn{5}{|l|}{ Echogenicity } & \multirow{5}{*}{$0.7 \mathrm{NS}$} & & & & & \multirow{5}{*}{$0.8 \mathrm{NS}$} \\
\hline Hypoechoic & 11 & 64.7 & 21 & 63.6 & & 4 & 66.7 & 26 & 63.4 & \\
\hline Hyperecoic & 0 & 0.0 & 2 & 6.1 & & 0 & 0.0 & 2 & 4.9 & \\
\hline Isoechoic & 1 & 5.9 & 3 & 9.1 & & 0 & 0.0 & 3 & 7.3 & \\
\hline Heterogeneous & 5 & 29.4 & 7 & 21.2 & & 2 & 33.3 & 10 & 24.4 & \\
\hline \multicolumn{5}{|l|}{ Halo } & \multirow{4}{*}{$<0.001 \mathrm{~S}$} & & & & & \multirow{4}{*}{$<0.001 \mathrm{~S}$} \\
\hline Present & 5 & 29.4 & 31 & 93.9 & & 1 & 16.7 & 35 & 85.4 & \\
\hline Interrupted & 4 & 23.5 & 0 & 0.0 & & 2 & 33.3 & 1 & 2.4 & \\
\hline Absent & 8 & 47.1 & 2 & 6.1 & & 3 & 50.0 & 5 & 12.2 & \\
\hline
\end{tabular}




\section{Journal of Endocrinology and Thyroid Research}

\begin{tabular}{|c|c|c|c|c|c|c|c|c|c|c|}
\hline \multicolumn{5}{|l|}{ Border } & \multirow{3}{*}{$0.047 \mathrm{~S}$} & & & & & \multirow{3}{*}{$0.004 \mathrm{~S}$} \\
\hline Well-defined & 9 & 52.9 & 27 & 81.8 & & 1 & 16.7 & 33 & 80.5 & \\
\hline Ill-defined & 8 & 47.1 & 6 & 18.2 & & 5 & 83.3 & 8 & 18.5 & \\
\hline \multicolumn{5}{|l|}{ Breakdown } & \multirow{5}{*}{$0.8 \mathrm{NS}$} & & & & & \multirow{5}{*}{$0.5 \mathrm{NS}$} \\
\hline Central & 4 & 23.5 & 12 & 36.4 & & 3 & 50.0 & 12 & 29.3 & \\
\hline Peripheral & 3 & 17.6 & 6 & 18.2 & & 0 & 0.0 & 8 & 19.5 & \\
\hline $\begin{array}{l}\text { Central + } \\
\text { Peripheral }\end{array}$ & 2 & 11.8 & 3 & 9.1 & & 1 & 16.7 & 4 & 9.8 & \\
\hline No breakdown & 8 & 47.1 & 12 & 36.4 & & 2 & 33.3 & 17 & 41.5 & \\
\hline \multicolumn{5}{|l|}{ Calcification } & \multirow{3}{*}{$0.02 \mathrm{~S}$} & & & & & \multirow{3}{*}{$0.007 \mathrm{~S}$} \\
\hline Present & 12 & 70.6 & 11 & 33.3 & & 6 & 100 & 16 & 39.0 & \\
\hline Absent & 5 & 29.4 & 22 & 66.7 & & 0 & 0.0 & 25 & 61.0 & \\
\hline \multicolumn{5}{|l|}{ Blood flow } & \multirow{5}{*}{$<0.001 \mathrm{~S}$} & & & & & \multirow{5}{*}{$0.001 \mathrm{~S}$} \\
\hline Central & 10 & 58.8 & 2 & 6.1 & & 5 & 83.3 & 5 & 12.2 & \\
\hline Peripheral & 3 & 17.6 & 24 & 72.7 & & 0 & 0.0 & 27 & 65.9 & \\
\hline $\begin{array}{c}\text { Central + } \\
\text { Peripheral }\end{array}$ & 4 & 23.5 & 5 & 15.2 & & 1 & 16.7 & 7 & 17.1 & \\
\hline No & 0 & & & & & 0 & 0.0 & 2 & 4.9 & \\
\hline LNS & & & & & \multirow{3}{*}{$0.01 \mathrm{~S}$} & & & & & \multirow{3}{*}{$<0.001 \mathrm{~S}$} \\
\hline Present & 4 & 23.5 & 0 & 0 & & 4 & 66.7 & 0 & 0.0 & \\
\hline Absent & 13 & 76.5 & 33 & 100 & & 2 & 33.3 & 41 & 100 & \\
\hline
\end{tabular}

Six malignant nodules were found to harbor BRAF V600E gene mutation, five of them were papillary thyroid carcinoma and one was follicular neoplasm by FNAC with P value 0.001 and nothing was found in benign nodules so there was significant

correlation between BRAF V600E gene mutation and papillary thyroid cancer. Overall, sensitivity of ultrasound in detecting malignancy was found to be $88.2 \%$, specificity $72.7 \%$, Sensitivity of US and BRAF V600E mutation combined was 92\% (Table 6).

Table 6: Sensitivity and Specificity of each parameter of U/S with malignant Cytology and BRAF v600E mutation.

\begin{tabular}{|c|c|c|c|c|c|c|c|c|c|c|}
\hline \multirow{2}{*}{ U/S Parameters } & \multicolumn{2}{|c|}{ Sensitivity } & \multicolumn{2}{|c|}{ Specificity } & \multicolumn{2}{|c|}{ PPV } & \multicolumn{2}{|c|}{ NPV } & \multicolumn{2}{|c|}{ Accuracy } \\
\hline & $\begin{array}{l}\text { Malign- } \\
\text { ancy }\end{array}$ & $\begin{array}{c}\text { Braf- } \\
\text { mutation }\end{array}$ & $\begin{array}{l}\text { Malign- } \\
\text { ancy }\end{array}$ & $\begin{array}{c}\text { Braf- } \\
\text { mutation }\end{array}$ & $\begin{array}{l}\text { Malign- } \\
\text { ancy }\end{array}$ & $\begin{array}{c}\text { Braf- } \\
\text { mutation }\end{array}$ & $\begin{array}{l}\text { Malign- } \\
\text { ancy }\end{array}$ & $\begin{array}{c}\text { Braf- } \\
\text { mutation }\end{array}$ & $\begin{array}{l}\text { Malign- } \\
\text { ancy }\end{array}$ & $\begin{array}{c}\text { Braf- } \\
\text { mutation }\end{array}$ \\
\hline $\begin{array}{c}\text { Hypo- } \\
\text { echogenicity }\end{array}$ & $66.7 \%$ & $64.7 \%$ & $36.6 \%$ & $36.4 \%$ & $13.3 \%$ & $34.4 \%$ & $88.2 \%$ & $66.7 \%$ & $40.4 \%$ & $46 \%$ \\
\hline $\begin{array}{l}\text { Micro- } \\
\text { calcification }\end{array}$ & $70.6 \%$ & $70.6 \%$ & $61 \%$ & $66.7 \%$ & $27.3 \%$ & $52.2 \%$ & $100 \%$ & $81.5 \%$ & $66 \%$ & $68 \%$ \\
\hline Irregular margins & $83.3 \%$ & $47.1 \%$ & $80.5 \%$ & $81.8 \%$ & $38.5 \%$ & $57.1 \%$ & $97.1 \%$ & $75 \%$ & $80.9 \%$ & $70 \%$ \\
\hline $\begin{array}{c}\text { Absence or } \\
\text { incomplete halo }\end{array}$ & $83.3 \%$ & $70.6 \%$ & $85.4 \%$ & $93.9 \%$ & $45.5 \%$ & $85.7 \%$ & $97.2 \%$ & $86.1 \%$ & $85.1 \%$ & $86 \%$ \\
\hline $\begin{array}{l}++ \text { intra-nodular } \\
\text { blood flow }\end{array}$ & $100 \%$ & $100 \%$ & $4.9 \%$ & $6.1 \%$ & $13.3 \%$ & $35.4 \%$ & $100 \%$ & $100 \%$ & $17 \%$ & $38 \%$ \\
\hline $\mathrm{AP} / \mathrm{T}>1$ & $83.3 \%$ & $52.9 \%$ & $90.2 \%$ & $97 \%$ & $55.6 \%$ & $90 \%$ & $97.4 \%$ & $80 \%$ & $89.4 \%$ & $82 \%$ \\
\hline Presence of LNS & $66.7 \%$ & $23.5 \%$ & $100 \%$ & $100 \%$ & $100 \%$ & $100 \%$ & $95.3 \%$ & $71.7 \%$ & $95.7 \%$ & $74 \%$ \\
\hline
\end{tabular}




\section{Discussion}

It is noticed that thyroid nodules more common finding in females more than males, Framingham survey for thyroid nodules shows that prevalence in females $6.4 \%$ and $1.5 \%$ in males, and the Whickham study displays (6.6:1 ratio females /males) [21], This might explain why most of the patients in our study were females representing $90 \%$. The incidence of malignancy in our study was $34 \%$ this result is biased because 12 nodules diagnosed as PTC are chosen retrograde after diagnosis of PTC to assess BRAF v600E mutation status.

The incidence of BRAF-V600E gene mutation in our patients with PTC was 55.6\%; previous meta-analyses have published values for the overall prevalence of the BRAF-V600E mutation in PTC ranging from 29 to $83 \%$. [10,22,23], this wide range may be due to variations in PTC subtype, subjects' geographical backgrounds, and research methodology.

No difference in BRAFV600E gene mutation incidence between different age groups and this shows agreement with Ah Young Park et al. [24], but regarding our result of absence of significant association of BRAFV600E gene mutation with special sex that shows disagreement with Ah Young Park et al. study that shows increase mutation in male sex, this may be due to the small number of cases involved in our study, also $90 \%$ of our cases are females that cannot reflect the actual prevalence [24].

Our study contained five nodules (10\%) with undetermined cytology, four of them have suspicious US features and all were negative regarding BRAF-V600E gene mutation, we can't exclude malignancy in these cases by absence of BRAF-V600E gene mutation alone as BRAF-V600E mutation is found only in nearly $40 \%$ of PTC cases [25].

The presence of BRAF-V600E mutation in one case of follicular neoplasm out of five cases shows agreement with only one case report Pennelli et al. [26], this conflicting result may be due to inadequate cytological diagnosis and interpretation as follicular variant of papillary cancer may be interpreted as a micro follicular lesion in FNA [27], so this case need follow up and pathological confirmation post thyroidectomy to make sure of this result.

In this present study BRAF-V600E mutation was negative in benign cases, this result shows agreement with other studies $[10,11]$ and BRAF-V600E mutation is believed to be specific for PTC because no report has been issued of this mutation in benign nodules [28].

The sensitivity of BRAF-V600E gene mutation in detecting PTC was $42.9 \%$, specificity was $100 \%$, positive predictive value $100 \%$, and accuracy $83 \%$, this result shows agreement with Kim et al that shows BRAF-V600E mutation alone has a specificity of $100 \%$ and a positive predictive value of $100 \%$ for diagnosing malignancy in PTC $[9,29]$.
Nam et al. [30] reported significant improvements in the sensitivity, negative predictive value, and diagnostic accuracy of FNA cytology for diagnosing malignancy by adding BRAF-V600E analysis to both US and FNAC [30].

Several studies have found a positive correlation between the BRAF-V600E mutation and suspicious sonographic features of thyroid nodules [7], other studies show inconsistent results; Kwak, et al. found that only marked hypo echogenicity was associated with BRAF-V600E positivity, Hwang et al. found that only calcification was associated with BRAF-V600E positivity $[29,31]$ both these studies predominantly evaluated small papillary thyroid micro carcinomas, with mean tumor sizes of $6-9 \mathrm{~mm} 3$, the small size was likely a significant confounding factor in characterizing these lesions by preoperative US.

Our study shows positive correlation between most suspicious US findings and BRAF-V600E gene mutation and shows that $\mathrm{AP} / \mathrm{T} \geq 1$, absent or incomplete halo, irregular border, micro-calcifications and Increase intra-nodular blood flow have positive correlation with positivity of BRAF-V600E mutation these results show agreement with Kabaker et al. [32] that showed association of BRAF-V600E positivity with most known suspicious U/S finding including taller than wide shape, illdefined margin, hypo-echogenicity, micro-calcifications and absent halo (p value $<0.001$ ) [32].

This study also showed that BRAF-V600E gene mutation is significantly present in cases with cervical lymphadenopathy this result shows agreement with many studies that correlate BRAFV600E gene mutation with the frequency of lymph node metastases [10,22] Park et al. [24] study concluded that the BRAF-V600E mutation was associated extra-thyroidal extension, central and lateral lymph node metastasis, and advanced tumor stage $(\mathrm{P}<0.0001$, so BRAFV600E analysis preoperative may be of value as prognostic marker and affect surgical decision regarding type of surgery.

DNA sequencing method shows high cost, time consuming and low sensitivity for the clinical screening of BRAF V600E mutation and this shows agreement with other study [33] that shows accuracy of DNA sequencing is low when dealing with cytological specimens where the cells in question may be a minor population among the vast majority of background nonneoplastic cells, Furthermore, this method needs expensive equipment which may not be economical for all the patients [34], In contrast HRMA has been proved to be applicable, costefficient and very sensitive scanning method that allows rapid detection of DNA sequence variations without cumbersome post-polymerase chain reaction (PCR) methods, which is not achievable by direct sequencing [35]. Because targeted therapy for thyroid cancers with multikinase inhibitors is under active development $[36,37]$, the detection of mutations in the FNAC material may be helpful in the future to guide mutation-specific targeted therapies that can be initiated preoperatively or in 
those patients who are not surgical candidates. This study has some limitations as small number of patients included, some genetic mutations should be included as RAS and RET and RET/ PTC rearrangement.

\section{Conclusion}

BRAFV600E positivity was associated with most known suspicious U/S finding, BRAFV600E gene mutation analysis is a new hopeful diagnostic and prognostic tool that helps to overcome limitations of high resolution neck ultrasonography and fine needle aspiration biopsy, Adding BRAF-V600E analysis to $\mathrm{U} / \mathrm{S}$ and FNA would increase the sensitivity of preoperative diagnosis of PTC especially in cases of indefinite nodules. HRMA is an excellent, simple, low cost tool for BRAF-V600E analysis in comparison to DNA sequencing method.

\section{Acknowledgement}

I'd like to Knowledge Dr. Marwa Abdel Naser (pathologist), Dr. Mohamed Mostafa for statistical support and also my institute.

\section{Financial Disclosure}

Fund and sponsorship for this research from Cairo University.

\section{References}

1. Frates MC, Benson CB, Charboneau JW, Cibas ES, Clark OH, et al. (2005) Management of thyroid nodules detected at US: society of radiologists in ultrasound consensus conference statement. Radiology 237(3): 794-800.

2. Yip L, Farris C, Kabaker AS, Hodak SP, Nikiforova MN, et al. (2012) Cost impact of molecular testing for indeterminate thyroid nodule fineneedle aspiration biopsies. The J Clin Endocrinol Metab 97(6): 19051912.

3. Alam T, Khattak YJ, Beg M, Raouf A, Azeemuddin M, et al. (2013) Diagnostic accuracy of ultrasonography in differentiating benign and malignant thyroid nodules using fine needle aspiration cytology as the reference standard. Asian Pac J Cancer Prev 15(22): 10039-10043.

4. Doddi S, Chohda E, Maghsoudi S, Sheehan L, Sinha A, et al. (2015) The final outcome of indeterminate cytology of thyroid nodules in a District General Hospital. G Chir 36(3): 122.

5. Kim TY, Kim WB, Rhee YS, Song JY, Kim JM, et al. (2006) The BRAF mutation is useful for prediction of clinical recurrence in low-risk patients with conventional papillary thyroid carcinoma. Clinical endocrinology (Oxf) 65(3): 364-368.

6. Feng L, Li M, Zhang QP, Piao ZA, Wang ZH, et al. (2011) Utility of BRAF protein overexpression in predicting the metastasis potential of papillary thyroid carcinoma. Oncol Lett 2(1): 59-63.

7. Lee EJ, Song KH, Kim DL, Jang YM, Hwang TS, et al. (2011) The BRAFV600E mutation is associated with malignant ultrasonographic features in thyroid nodules. Clin Endocrinol (Oxf) 75(6): 844-850.

8. Liu X, Medici M, Kwong N, Angell TE, Marqusee E, et al. (2016) Bethesda categorization of thyroid nodule cytology and prediction of thyroid cancer type and prognosis. Thyroid 26(2): 256-261.

9. Gharib H, Papini E, Garber JR, Duick DS, Harrell RM, et al. (2016) American Association of Clinical Endocrinologists, American College Of Endocrinology, and Associazione Medici Endocrinologi Medical Guidelines For Clinical Practice For The Diagnosis and Management of Thyroid Nodules-2016 Update. Endocr Pract 22(5): 622-639.

10. Xing M (2005) BRAF mutation in thyroid cancer. Endocr Relat Cancer 12(2): $245-262$.
11. Xing M (2007) BRAF mutation in papillary thyroid cancer: pathogenic role, molecular bases, and clinical implications. Endocr Rev 28(7): 742762 .

12. Vossen RH, Aten E, Roos A, den Dunnen JT (2009) High-Resolution Melting Analysis (HRMA)-More than just sequence variant screening. Hum Mutat 30(6): 860-866.

13. Yoon JH, Kwak JY, Moon HJ, Kim MJ, Kim EK (2011) The diagnostic accuracy of ultrasound-guided fine-needle aspiration biopsy and the sonographic differences between benign and malignant thyroid nodules 3cm or larger. Thyroid 21(9): 993-1000.

14. Moon HJ, Kwak JY, Kim EK, Kim MJ (2011) A taller-than-wide shape in thyroid nodules in transverse and longitudinal ultrasonographic planes and the prediction of malignancy. Thyroid 21(11): 1249-1253.

15. Moses W, Weng J, Sansano I, Peng M, Khanafshar E, et al. (2010) Molecular testing for somatic mutations improves the accuracy of thyroid fine-needle aspiration biopsy. World J Surg 34(11): 2589-2594.

16. Yoo MR, Gweon HM, Park AY, Cho KE, Kim JA, et al. (2015) Repeat Diagnoses of Bethesda Category III Thyroid Nodules: What To Do Next? PloS one 10(6): e0130138.

17. Nikiforov YE, Nikiforova MN (2011) Molecular genetics and diagnosis of thyroid cancer. Nat Rev Endocrinol 7(10): 569-580.

18. D'Souza MM, Marwaha RK, Sharma R, Jaimini A, Thomas S, et al. (2010) Prospective evaluation of solitary thyroid nodule on 18F-FDG PET/CT and high-resolution ultrasonography. Ann Nucl Med 24(5): 345-355.

19. Xing M (2010) Prognostic utility of BRAF mutation in papillary thyroid cancer. Mol Cell Endocrinol 321(1): 86-93.

20. Xing M (2016) Diagnostic and Prognostic Molecular Markers in Thyroid Cancer. Thyroid Cancer pp. 281-292.

21. Vander JB, Gaston EA, Dawber TR (1968) The significance of nontoxic thyroid nodules: final report of a 15-year study of the incidence of thyroid malignancy. Ann Intern Med 69(3): 537-540.

22. Lee JH, Lee ES, Kim YS (2007) Clinicopathologic significance of BRAF V600E mutation in papillary carcinomas of the thyroid. Cancer 110(1): 38-46.

23. Witt RL, Ferris RL, Pribitkin EA, Sherman SI, Steward DL, et al. (2013) Diagnosis and management of differentiated thyroid cancer using molecular biology. Laryngoscope 123(4): 1059-1064.

24. Park AY, Son EJ, Kim JA, Youk JH, Park YJ, et al. (2014) Associations of the BRAF V600E Mutation with Sonographic Features and Clinicopathologic Characteristics in a Large Population with Conventional Papillary Thyroid Carcinoma. PloS one 9(10): e110868.

25. Fugazzola L, Puxeddu E, Avenia N, Romei C, Cirello V, et al. (2006) Correlation between B-RAFV600E mutation and clinic-pathologic parameters in papillary thyroid carcinoma: data from a multicentric Italian study and review of the literature. Endocr Relat Cancer 13(2): 455-464.

26. Pennelli G, Vianello F, Barollo S, Pezzani R, Merante Boschin I, et al. (2011) BRAF K601E Mutation in a Patient with a Follicular Thyroid Carcinoma. Thyroid 21(12): 1393-1396.

27. Jain M, Khan A, Patwardhan N, Reale F, Safran M (2001) Follicular variant of papillary thyroid carcinoma: a comparative study of histopathologic features and cytology results in 141 patients. Endocrine Practice 7(2) 79-84.

28. Pizzolanti G, Russo L, Richiusa P, Bronte V, Nuara RB, et al. (2007) Fineneedle aspiration molecular analysis for the diagnosis of papillary thyroid carcinoma through BRAFV600E mutation and RET/PTC rearrangement. Thyroid 17(11): 1109-1115.

29. Kim SK, Hwang TS, Yoo YB, Han HS, Kim DL, et al. (2011) Surgical results of thyroid nodules according to a management guideline based on the BRAFV600E mutation status. The J Clin Endocrinol Metab 96(3): 658-664. 
30. Nam SY, Han BK, Ko EY, Kang SS, Hahn SY, et al. (2010) BRAF V600E mutation analysis of thyroid nodules needle aspirates in relation to their ultrasongraphic classification: a potential guide for selection of samples for molecular analysis. Thyroid 20(3): 273-279.

31. Jiyoung Hwang, Jung Hee Shin, Boo-Kyung Han, Eun Young Ko, Seok Seon Kang, et al. (2010) Papillary thyroid carcinoma with BRAF V600E mutation: sonographic prediction. American Journal of Roentgenology 194(5): W425-W430.

32. Kabaker AS, Tublin ME, Nikiforov YE, Armstrong MJ, Hodak SP, et al. (2012) Suspicious ultrasound characteristics predict BRAF V600Epositive papillary thyroid carcinoma. Thyroid 22(6): 585-589.

33. Pichler M, Balic M, Stadelmeyer E, Ausch C, Wild M, et al. (2009) Evaluation of high-resolution melting analysis as a diagnostic tool to detect the BRAF V600E mutation in colorectal tumors. J Mol Diagn 11(2): 140-147.

34. Ziai J, Hui P (2012) BRAF mutation testing in clinical practice. Expert review of molecular diagnostics 12(2): 127-138.

35. Simi L, Pratesi N, Vignoli M, Sestini R, Cianchi F, et al. (2008) Highresolution melting analysis for rapid detection of KRAS, BRAF, and PIK3CA gene mutations in colorectal cancer. Am J Clin Pathol 130(2): 247-253.

36. Espinosa AV, Porchia L, Ringel MD (2007) Targeting BRAF in thyroid cancer. Br J Cancer 96(1): 16-20.

37. Fagin JA (2007) The Jeremiah Metzger Lecture: intelligent design of cancer therapy: trials and tribulations. Trans Am Clin Climatol Assoc 118: $253-261$.
This work is licensed under Creative Commons Attribution 4.0 Licens

DOI: 10.19080/JETR.2017.02.555580
Your next submission with Juniper Publishers will reach you the below assets

- Quality Editorial service

- Swift Peer Review

- Reprints availability

- E-prints Service

- Manuscript Podcast for convenient understanding

- Global attainment for your research

- Manuscript accessibility in different formats

(Pdf, E-pub, Full Text, Audio)

- Unceasing customer service

Track the below URL for one-step submission https://juniperpublishers.com/online-submission.php 